\title{
Phytopharmacognostic Evaluation and Fourier Transform Infrared Fingerprint in the Quality Control of Various Culinary Herbs: An Ultimate Remedy in Asia
}

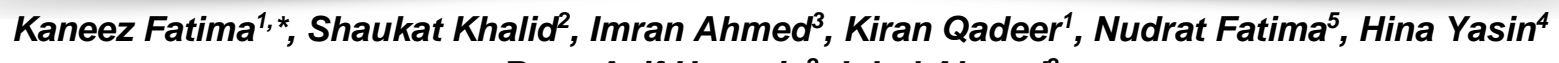

Rana Asif Hussain ${ }^{2}$, Iqbal Ahamd²

${ }^{1}$ Institute of Pharmaceutical Sciences, Jinnah Sindh Medical University, Rafiqi H J Road, Karachi Cantonment, Karachi-75510, Pakistan.

${ }^{2}$ Baqai Institute of Pharmaceutical Sciences, Baqai Medical University, Toll Plaza, Super Highway, Gadap Road, Karachi-75270, Pakistan.

${ }^{3}$ Department. of Pharmacy, National Institute of Heart Diseases, NICVD, Sukkar, Pakistan.

${ }^{4}$ Faculty of Pharmacy, Dow University of health sciences, 4/B, Shahrah-e-Ghalib, Clifton, Karachi, 75600,

Pakistan.

${ }^{5}$ Faculty of Pharmacy, Jinnah University for Women, Karachi, 5-C Nazimabad Karachi-74600, Pakistan.

Authors' Contributions

1, 6 Drafting of Manuscript.

2 Conception \& Study design.

3, 7 Data Collection \& Processing.

4 Data Analysis and/or Interpretation.

5, 8 Critical Review.

\section{Article info.}

Received: March 16, 2021

Accepted: May 08, 2021

Funding Source: Nil

Conflict of Interest: Nil

Cite this article: Fatima $K, S$, Khalid $S$, Ahmed I, Qadeer K, Fatima N, Yasin H, Hussain RA, Ahamd I. Phytopharmacognostic Evaluation and Fourier Transform Infrared Fingerprint in the Quality Control of Various Culinary Herbs: An Ultimate Remedy in Asia. RADS J Pharm Pharm Sci. 2021; 9(1):47-59.

*Address of Correspondence Author: dr.kaneezfatima@outlook.com

\section{A B S TRACT}

Background: The quality and efficacy of culinary herbs commonly practiced in Asia as a remedy for seasonal illnesses such as cold, flu, congestion, fever and inflammation, etc. The extemporaneous preparations of these culinary herbs are being formulated as traditional practice either in the form of extract, decoction, and paste etc. These culinary herbs are being practiced for curing sporadic illnesses since ancient time.

Objectives: In present study five herbs' i.e. Elettaria cardamomum (cardamom), Cinnamomum zeylanicum (cinnamon), Carum carvi (caraway), Oreganum vulgare (oregano) and Syzygium aromaticum (clove) have been obtained from the market to assure quality of herbs in local market.

Methodology: Various quality control tests including microscopic evaluation, physico-chemical characteristics, Thin layer chromatography (TLC) and Fourier Transform Infrared spectroscopy (FTIR) have been performed to determine their compliance with the standards. The TLC has been used for the identification of the active ingredients on comparison of their $\mathrm{Rf}$ values with the reference standard. FTIR Spectra of these materials have been obtained to identify and confirm structural information and assignment of functional groups.

Results: Many of the herbal samples used in this study have been complied with the available official standards as given in Pharmacopoeia. If the samples did not comply with the standards then it indicates that the sample belongs to spurious quality of raw herb, which is the prime cause that may interfere with the therapeutic efficacy and variability of outcomes.

Conclusion: This study help to provide a significant data to herbal drug manufacturers for authentication of commercially available herbs which may be used in the formulation of extemporaneous or commercially available herbal medicine. 
Phytopharmacognostic Evaluation and Fourier Transform Infrared Fingerprint in the Quality Control of Various Culinary Herbs: An Ultimate Remedy in Asia

Keywords: Culinary herbs, Pharmacognostic studies, Thin-layer chromatography, Fourier transform infrared spectroscopy.

\section{INTRODUCTION}

Medicinally affluent floras are accessible all around the world. Asian countries have well established and extended system of herbal medicine. Western countries also adopted this system as an alternative line of therapy [1]. According to latest survey, every third prescription contains alternative or herbal medicine to produce synergistic effect in treatment line of any ailments [2]. The geological and geographical study indicates that various regions of Pakistan are enrich source herbs with medicinal value or are cultivated on farmlands [3, 4].

However, herbal raw material and herbal derived product represent considerable section of international market and due to this globally documented guidelines for their quality control are necessary [5]. The quality of medicinal plant materials intended for pharmaceutical purpose must be as high as that of other medicinal preparations [6,7].

Now herbal drugs are considered as the potential source of novel drug discovery [8]. Several studies show that herbal drugs are needed to be standardized prior its use in formulation to confirm uniformity and quality of the product. Various ailments are treated by naturally occurring herbs while modern system of medicine lost this benefit due to variation of active content [9].

According to WHO guidelines for standardization of Herbs there should be reference to the identity, physicochemical characters, pharmacological parameters, toxicity details, microbial and radioactive contamination [10-12].

Culinary herbs are plant material not only used traditionally in cookery due to natural flavor but also possess medicinal value [13]. Some examples are: chives, oregano, dill, basil and parsley [14]. People are turning back their life towards more natural and simple way that's why fresh herbs and organic food become trendy in order to stay healthy. Some of the popular herbs that are used in the kitchen as condiment and spices having significant medicinal value and health benefits are Elettaria cardamomum, Cinnamomum zeylanicum, Carum carvi, Oreganum vulgare and Syzigium aromaticum.
These culinary herbs have been experimented for its quality to produce maximum therapeutic outcome [6, 15].

The present research article emphasizes upon standardization of culinary herbs as well as focus on the methods used for analysis of these herbs drug. These steps are taken to ensure the prior exhaustion of herbs that is being a common practice in local market which ultimately leads to reduced therapeutic outcomes. Thus to overcome these obstacles there are many standards and parameters set by different pharmacopeias, and recommended guidelines set by the WHO remain most significant.

The purpose of standardization is tremendously extensive and widespread. A sound knowledge of these important culinary herbs found commonly in Pakistan and extensively used as folk remedy is of extreme significance. The availability of standardized herbs in the market would bring trust of individuals toward herbal remedy and uniform therapeutic outcomes.

Furthermore, Pakistan can develop as the major country in production of standardized, therapeutically effective herbal formulations because Pakistan is ironic source of medicinally vigorous herbs. This can be accomplished only if these plants are analyzed through sophisticated and modern methods of standardization.

The object of this study is to design a protocol for the authentication of commercially available herbs. Clinically effective herbs can only be preserved by transient implementation of suitable quality control parameters already mentioned in British Pharmacopeias.

\section{MATERIALS AND METHODS}

\section{Assortment and nomenclature of culinary herb}

Five commercially available culinary herbs were collected from native market place of Karachi. that included Elettaria cardamomum, Cinnamomum zeylanicum, Carum carvi, Oreganum vulgare and Syzigium aromaticum. The herbs were identified in herbarium of department of pharmacognosy, Baqai Institute of Pharmaceutical sciences, Karachi and 
deposited with accession number 004PHCOG2485. These culinary herbs were sampled in the range of 3 5 according to their availability. The samples of the culinary herbs were coded as: Elettaria cardamomum (Cd 1- Cd5), Cinnamomum zeylanicum(Ci-1 - Ci 5), Carum carvi(Ca 1- Ca 5), Oreganum vulgare(O 1$\mathrm{O} 2)$ and Syzigium aromaticum $(\mathrm{Cl} 1-\mathrm{Cl} 5)$ [16].The authentic reference standards of the constituents of the crude drugs were obtained from Sigma Aldrich Co.

\section{Assessment of crude drugs}

The Plant materials were subjected to various quality control tests mentioned in the British Pharmacopoeia [17] to conform their authenticity. The techniques used for the evaluation of crude drugs included microscopic evaluation, physicochemical parameters (foreign matter, Moisture content, ash value), thin layer chromatography and Fourier transformer infrared spectroscopy $[18,19]$.

\section{Determination of Foreign matter}

The foreign matter was tested according to the method given in British Pharmacopoeia [17] and the $\%$ was calculated using following formula.

Percentforeignmatter $=\frac{\text { foreignmatterweight }}{\text { totalweightof sample }} * 100$

\section{Determination of Moisture content}

The samples of all herbs were tested for moisture content using moisture analyzer at a temperature of $120^{\circ} \mathrm{C}$ according to BP method[17] and calculated with the help of following formula.

$\% M C=\frac{\text { Weightof sample }- \text { weightafterdrying }}{\text { weightof sample }} * 100$

\section{Determination of Total ash value (\%)}

Ash content was also determinedaccording to BP method [17] and calculated through formula given below:

$$
\text { Ashvalue }=\frac{\text { weighto fash }}{\text { weightof sample }} 100
$$

\section{Assay for volatile oil}

For the assay of volatile oil content, $20 \mathrm{~g}$ seeds were taken and distilled for five hours and assay was carried out according to method reported for each plant in BP [17]. The result was calculated in terms of $\mathrm{ml} / \mathrm{kg}$ of plant material.

\section{Thin-layer chromatography}

For Thin layer chromatography GF54 silica gel plates were used and $10 \mu \mathrm{L}$ sample was applied through microsyringe. Different sample was run using Methylene chloride R (Elettaria cardamomum, Cinnamomum zeylanicum,Oreganum vulgare), ethyl acetate $\mathrm{R}$ and toluene $\mathrm{R}(5: 95 \mathrm{v} / \mathrm{v})$ (Carum carvi) and toluene $\mathrm{R}$ (Cinnamomum zeylanicum) as mobile phase respectively. The plates were air dried and examined under ultraviolet light at $254 \mathrm{~nm}$ and 365 $\mathrm{nm}$ to mark the quenching zones and fluorescent zones respectively.

\section{Assay for \% of volatile oil}

The determination of essential oils is carried in the selected samples of Elettaria cardamomum, Cinnamomum zeylanicum, Carum carvi, Oreganum vulgare and Syzigium aromaticum. A specified quantity of drug was reduced to powder and taken immediately in a round-bottomed flask with $200 \mathrm{ml}$ of water $\mathrm{R}$ and $0.5 \mathrm{ml}$ of xylene $\mathrm{R}$. The mixture was distilled for 1.5 hours at the rate $2-3 \mathrm{ml} / \mathrm{min}$ for 90 minutes. Percentage of essential oil was calculated.

\section{Fourier transform infrared spectroscopy (FTIR)}

Ten milligram of the dried extract powder wasused to prepare a $100 \mathrm{mg} \mathrm{KBr}$ disc. The disc was placed in the FTIR spectrometer (Shimadzu, IR Affinity 1, Japan) and the spectrum obtained in the range of 400 to $4000 \mathrm{~cm}^{-1}$ with a resolution of $4 \mathrm{~cm}^{-1}[20]$.

\section{RESULTS}

Several quality control tests were performed to scrutinize the quality and validity of different commercially available culinary herbs [17, 21].

\section{Microscopic evaluation}

The microscopic evaluation of selected herbs was conducted via camera mounted microscope (Nikon DS-FI3) and pictures were captured (Figure 1-5). The characteristic features of the microscopic examination of selected herbs i.e. Elettaria cardamomum, Cinnamomum zeylanicum, Carum carvi, Oreganum vulgare and Syzigium aromaticum are given in Table 1. 
Table1. Characteristic features of the powder microscopy of Test samples.

\begin{tabular}{|c|c|c|c|c|c|}
\hline & $\begin{array}{c}\text { Elettaria } \\
\text { cardamom }\end{array}$ & $\begin{array}{c}\text { Cinnamomum } \\
\text { zeylinicum }\end{array}$ & Carum Carvi & $\begin{array}{c}\text { Origanum } \\
\text { vulgare }\end{array}$ & $\begin{array}{c}\text { Syzigium } \\
\text { aromaticum }\end{array}$ \\
\hline A & $\begin{array}{c}\text { Parenchymatous } \\
\text { cells }\end{array}$ & $\begin{array}{l}\text { Thickened wall, } \\
\text { channelled and } \\
\text { pitted Sclereid } \\
\text { cells }\end{array}$ & $\begin{array}{c}\text { Spiral vessels } \\
\text { accompanied by } \\
\text { sclerenchymatous } \\
\text { fibres }\end{array}$ & Parenchymal cells & $\begin{array}{l}\text { Hypanthium } \\
\text { containing large } \\
\text { oil glands }\end{array}$ \\
\hline B & $\begin{array}{l}\text { Testa made up of } \\
\text { outer epidermis } \\
\text { and parenchyma } \\
\text { cells }\end{array}$ & Cork fragments & $\begin{array}{l}\text { Rectangular to sub- } \\
\text { rectangular } \\
\text { sclereids }\end{array}$ & $\begin{array}{l}\text { Fragments of the } \\
\text { lower epidermis }\end{array}$ & Tiny fibres \\
\hline C & $\begin{array}{l}\text { A layer rectangular } \\
\text { cells enclosed with } \\
\text { volatile oil }\end{array}$ & $\begin{array}{c}\text { Cells with lignified } \\
\text { walls and narrow } \\
\text { lumen }\end{array}$ & $\begin{array}{c}\text { Numerous } \\
\text { endosperm } \\
\text { fragments } \\
\text { containing aleurone } \\
\text { grains }\end{array}$ & Stomata & $\begin{array}{l}\text { Parenchyma } \\
\text { cells enclosed } \\
\text { calcium oxalate } \\
\text { crystals }\end{array}$ \\
\hline D & $\begin{array}{l}\text { Sheet of cells } \\
\text { which are thin- } \\
\text { walled and } \\
\text { flattened }\end{array}$ & $\begin{array}{l}\text { Parenchymatous } \\
\text { cells enclosed } \\
\text { with calcium } \\
\text { oxalate crystals }\end{array}$ & $\begin{array}{c}\text { Fragments of } \\
\text { yellowish-brown, } \\
\text { thin-walled, } \\
\text { polygonal secretory } \\
\text { cells }\end{array}$ & $\begin{array}{c}\text { Covering } \\
\text { trichomes and } \\
\text { glandular } \\
\text { trichomes } \\
\text { Fine needles of } \\
\text { calcium oxalate }\end{array}$ & $\begin{array}{l}\text { Multiple pollen } \\
\text { grains triangular } \\
\text { in shape }\end{array}$ \\
\hline $\mathbf{E}$ & $\begin{array}{c}\text { Thick-walled } \\
\text { sclerenchymatous } \\
\text { cells }\end{array}$ & $\begin{array}{c}\text { Parenchymatous } \\
\text { cells }\end{array}$ & $\begin{array}{l}\text { Fragments of the } \\
\text { epicarp with thick- } \\
\text { walled cells and } \\
\text { occasional } \\
\text { anomocytic stomata }\end{array}$ & $\begin{array}{l}\text { Pollen grains, with } \\
\text { smooth exine }\end{array}$ & Trichome \\
\hline $\mathbf{F}$ & $\begin{array}{l}\text { Endosperm } \\
\text { parenchymatous, } \\
\text { thin-walled }\end{array}$ & - & Trichome & $\begin{array}{l}\text { Cells with finely } \\
\text { and irregularly } \\
\text { thickened walls, } \\
\text { diacytic stomata }\end{array}$ & $\begin{array}{l}\text { Rectangular to } \\
\text { sub-rectangular } \\
\text { sclereids }\end{array}$ \\
\hline
\end{tabular}

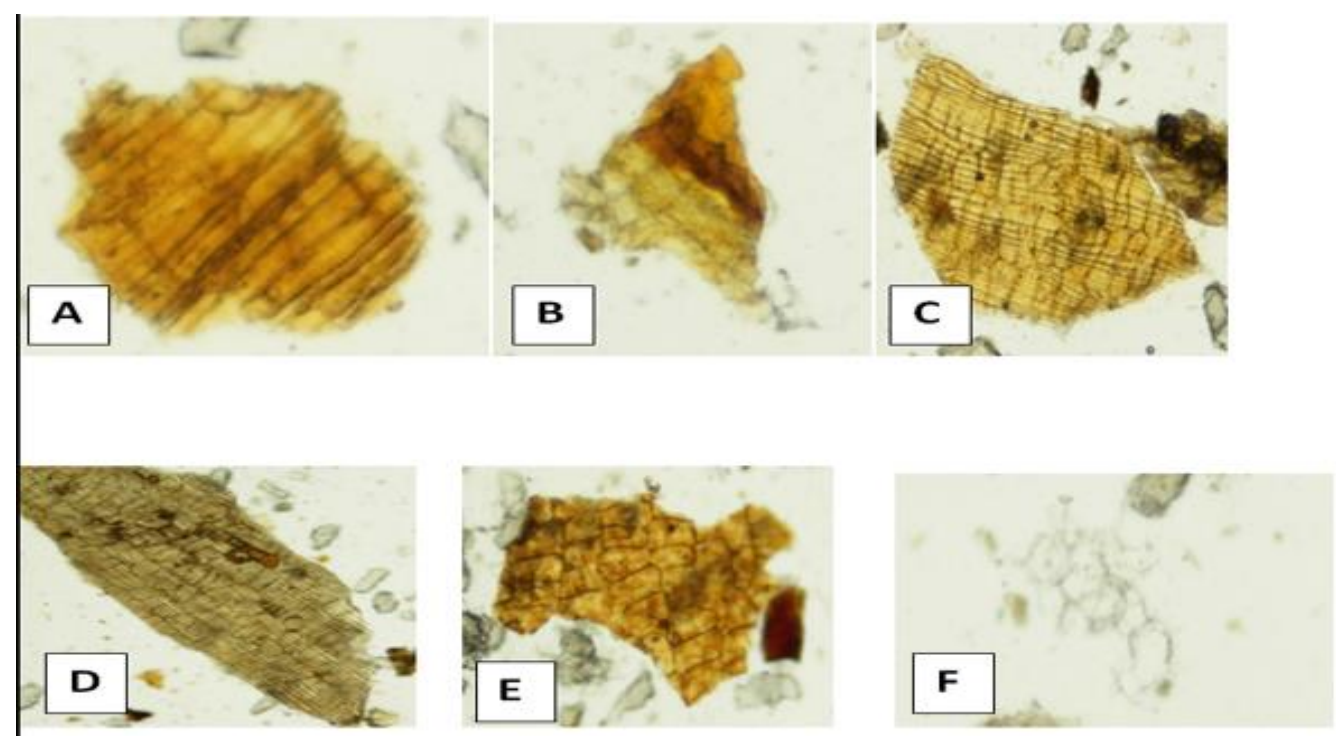

Figure1. Powder Microscopy of Elettaria cardamom. 
Phytopharmacognostic Evaluation and Fourier Transform Infrared Fingerprint in the Quality Control of Various Culinary Herbs: An Ultimate Remedy in Asia
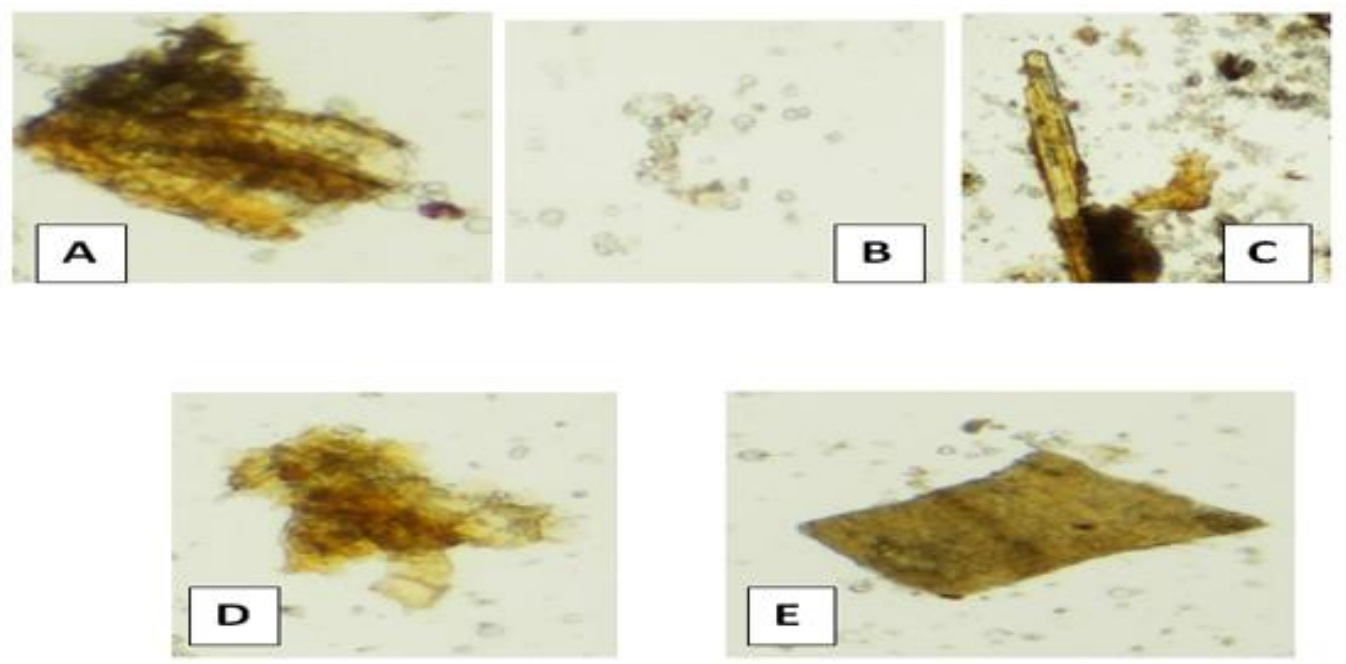

Figure 2. Powder Microscopy of Cinnamomum zeylinicum.
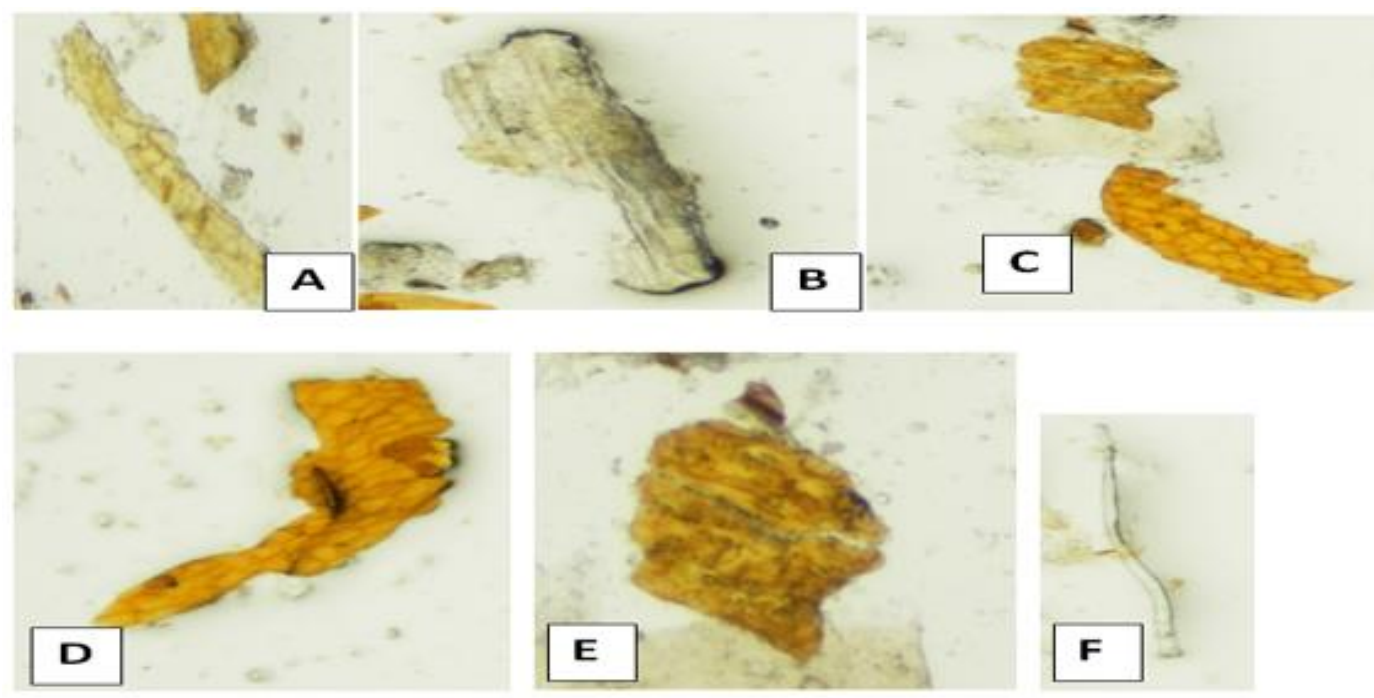

Figure 3. Powder Microscopy of Carum carvi.
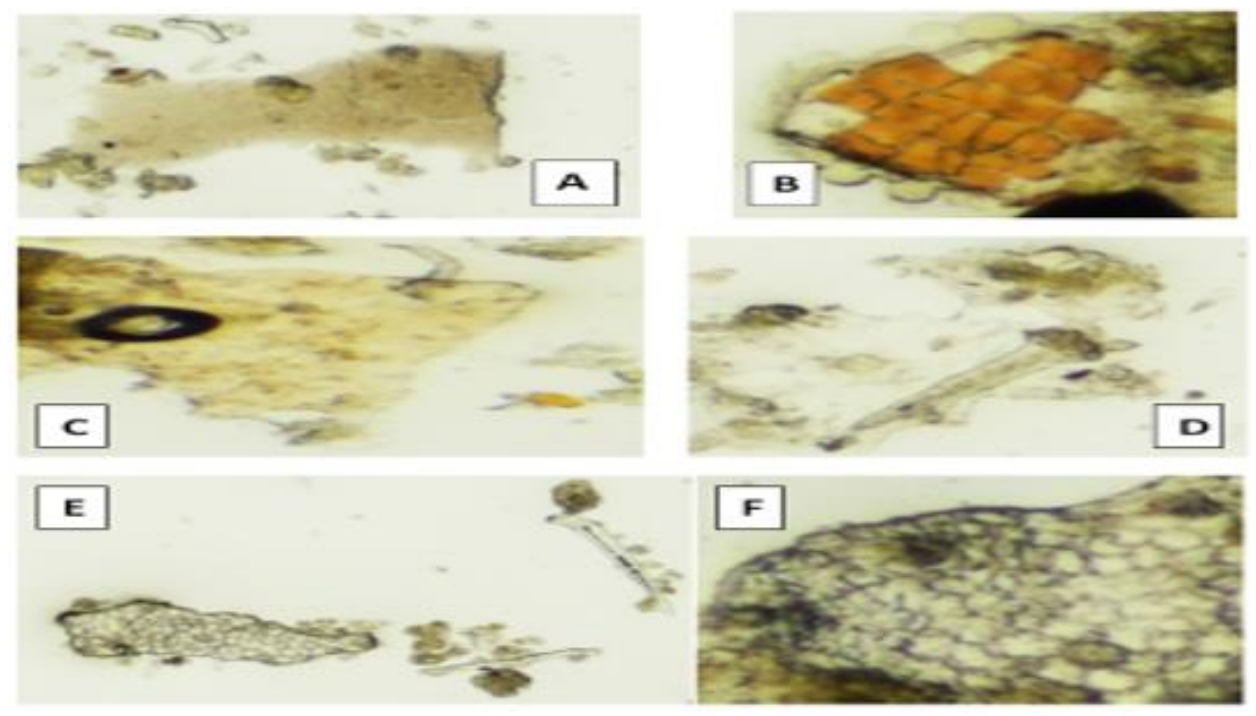

Figure 4. Powder Microscopy of Origanum vulgare. 

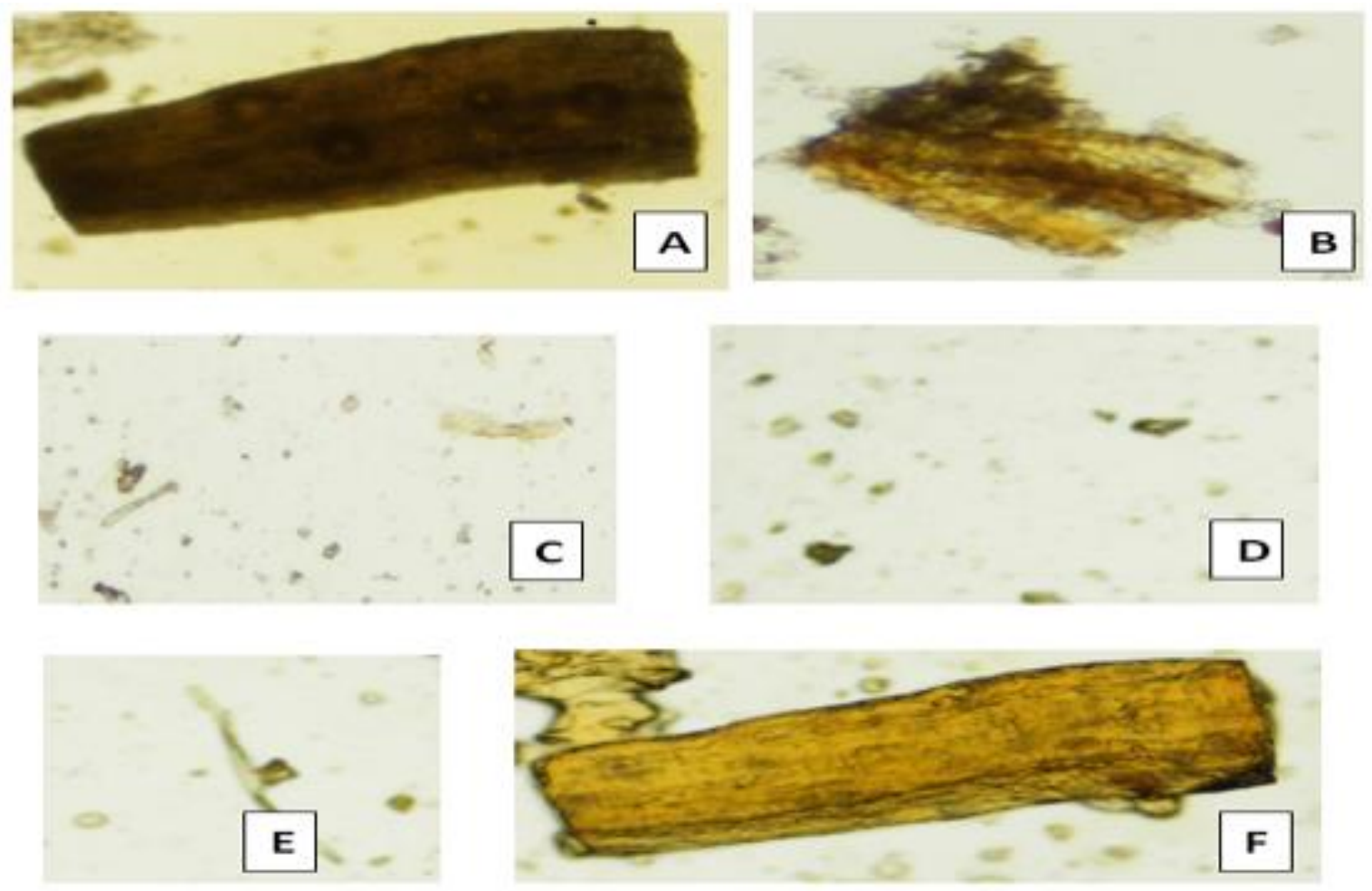

Figure 5. Powder Microscopy of Syzigium aromaticum.

\section{Physico-chemical tests}

All the culinary herbs [22] were subjected to different physicochemical tests and the results obtained are presented in Table 2.

\section{Foreign matter}

It is determined as the foreign matter is organic (Moulds, In-sects, Animal excreta etc.) or Inorganic (Stone, soil etc).Manual method and Lycopodium spore method are used to determine the foreign organic matters present in the samples. The percent foreign matter of Elettaria cardamom samples are between $0.64-1.00$ and Syzigium aromaticum samples are between 0.12-0.77 (Table 2). Foreign matter test is not recommended in BP for other three herbs i.e. Cinnamomum zeylanicum, Carum carvi and Oreganum vulgare [17].

\section{Moisture content}

For moisture content determination, the sample was heated at $105^{\circ} \mathrm{C}$ in oven until a constant weight is obtained [17]. The moisture content of Elettaria cardamom, Cinnamomum zeylinicum, Carum carvi, Origanum vulgare, and Syzigium aromaticum was found to be in the range of $6.91-8.72 \%, 5.56-6.91 \%$, $5.30-6.33 \%, 4.4-5.9 \%$ and $7.33-8.01 \%$ respectively (Table 2). Thus, the moisture content of all samples was found within BP limits i.e. 10\% [17]. Hence, the good quality of culinary herb indicates low content of moisture.

\section{Ash content}

The total ash value is the amount of test drug left after ignition. This test is carried out at low temperatures to avoid loss of alkali chlorides. The total ash consists of carbonates, phosphates, silicates and silica. The Ash content is one of the significant physicochemical parameter to assess the quality of drugs such as Elettaria cardamom, Cinnamomum zeylinicum, Carum Carvi, Origanum vulgare, and Syzigium aromaticum has been found in the range of 5.5-6.1, $5.49-6.00,6.4-7.0,14.2-15.1,6.89-7.40 \%$ respectively (Table 2). All the samples comply with the BP limit of $6.0,6.0,7.0,15.0$, and $7.0 \%$ respectively [17]. 
Table 2. Physicochemical Parameters of the selected samples of Elettaria cardamom,cinnamomum zeylinicum, Carum Carvi, Origanum vulgareand Syzigium aromaticum.

\begin{tabular}{|c|c|c|c|}
\hline Samples & \multicolumn{3}{|c|}{ Physicochemical Parameters } \\
\hline Elettaria cardamom & Foreign matter & MC (Moisture Content) +1 & Total ash \\
\hline Cd-1 & 0.64 & 7.39 & 6.0 \\
\hline Cd-2 & 0.68 & 7.72 & 5.5 \\
\hline Cd-3 & 0.71 & 8.72 & 6.0 \\
\hline Cd-4 & 0.98 & 6.91 & 5.7 \\
\hline Cd-5 & 1.00 & 7.56 & 5.6 \\
\hline Cinnamomum zeylinicum & Foreign matter & $\mathrm{MC}_{-}^{+} 0.5$ & Ash value \\
\hline $\mathrm{Ci}-1$ & Not recommended in BP & 6.39 & 6.00 \\
\hline $\mathrm{Ci}-2$ & - & 6.72 & 5.89 \\
\hline Ci-3 & - & 5.72 & 5.93 \\
\hline $\mathrm{Ci}-4$ & - & 6.91 & 5.49 \\
\hline Ci-5 & - & 5.56 & 6.00 \\
\hline Carum carvi & Foreign matter & MC & Ash value \\
\hline $\mathrm{Ca}-1$ & Not recommended in BP & 5.56 & 6.4 \\
\hline Ca-2 & - & 5.28 & 6.6 \\
\hline $\mathrm{Ca}-3$ & - & 5.30 & 7.0 \\
\hline $\mathrm{Ca}-4$ & - & 6.33 & 7.0 \\
\hline $\mathrm{Ca}-5$ & - & 5.46 & 6.6 \\
\hline Origanum vulgare & Foreign matter & MC & Ash value \\
\hline O-1 & Not recommended in BP & 4.4 & 14.2 \\
\hline $0-2$ & - & 5.9 & 14.6 \\
\hline $0-3$ & - & 4.6 & 15.0 \\
\hline O-4 & - & 5.6 & 15.0 \\
\hline $0-5$ & - & 4.6 & 14.2 \\
\hline Syzigium aromaticum & Foreign matter & MC & Ash value \\
\hline $\mathrm{Cl}-1$ & 0.1 & 8.0 & 7.0 \\
\hline $\mathrm{Cl}-2$ & 0.7 & 7.3 & 6.8 \\
\hline $\mathrm{Cl}-3$ & 0.1 & 7.5 & 6.9 \\
\hline $\mathrm{Cl}-1$ & 0.3 & 7.9 & 7.0 \\
\hline $\mathrm{Cl}-1$ & 0.2 & 7.9 & 6.8 \\
\hline
\end{tabular}

\section{Thin layer chromatography (TLC)}

TLC is a separation, identification and impurity detection of herbal drug in the formulation or in the extract. The herbal drug shows variability in its chemical constituents according to various locations/weather. To avoid any erroneous identification chromatographic fingerprint remained the assessment of choice. TLC studies revealed the presence of anethole in the samples of Elettaria cardamom (Cd-1 to $\mathrm{Cd}-5)$ with a $\mathrm{R}_{\mathrm{f}}$ value 0.78 that corresponds to the standard spot of 1,8-cineole. The samples of Cinnamomum zeylinicum (Ci-1, to $\mathrm{Ci}-5)$ all the samples showed the spots of that corresponded to the standard spot of cinnamic aldehyde. The $R_{f}$ value of the test samples are between 0.50-0.61 which is within the range of the standard. The slight deviation in Rfmay be due to high water content and any variation in the solvent system. Similarly the $R_{f}$ value of remaining three samples of Carum carvi ( $\mathrm{Ca}$ 1- Ca 5), Origanum vulgare (O 1- O 2), and Syzigium aromaticum $(\mathrm{Cl} 1-\mathrm{Cl} 5)$ also corresponded to their standard i.e. carvone, thymol and eugenol as shown in Table 3. 
Phytopharmacognostic Evaluation and Fourier Transform Infrared Fingerprint in the Quality Control of Various Culinary Herbs: An Ultimate Remedy in Asia

Table 3. Qualitative determination of the selected samples of Elettaria cardamom, Cinnamomum zeylinicum, Carum Carvi, Origanum vulgare, and Eugenia caryophyllusby TLC technique.

\begin{tabular}{|c|c|}
\hline Samples & $\mathbf{R}_{\mathbf{f}}$ value \\
\hline Elettaria cardamom & $\mathbf{1 , 8}$-cineole \\
\hline Cd-1 & 0.78 \\
\hline Cd-2 & 0.78 \\
\hline Cd-3 & 0.78 \\
\hline Cd-4 & 0.78 \\
\hline Cd-5 & 0.78 \\
\hline Cinnamomum zeylinicum & Cinnamic aldehyde \\
\hline Ci-1 & 0.60 \\
\hline Ci-3 & 0.61 \\
\hline Ci-4 & 0.53 \\
\hline Ci-5 & 0.50 \\
\hline Carum carvi & 0.60 \\
\hline Ca-1 & Carvone \\
\hline Ca -2 & 0.52 \\
\hline Ca -3 & 0.53 \\
\hline Ca -4 & 0.54 \\
\hline Ca -5 & 0.54 \\
\hline Origanum vulgare & 0.54 \\
\hline O-1 & Thymol \\
\hline O-2 & 0.50 \\
\hline O-3 & 0.49 \\
\hline O-4 & 0.50 \\
\hline O-5 & 0.50 \\
\hline Syzigium aromaticum & 0.50 \\
\hline Cl-1 & Eugenol \\
\hline Cl-2 & 0.74 \\
\hline Cl-4 & 0.75 \\
\hline Cl-5 & 0.82 \\
\hline & 0.81 \\
\hline & 0.82 \\
\hline
\end{tabular}

\section{Assay for \% volatile oil}

The value of essential oil has been determined to confirm the presence of volatile oil in selected samples of culinary herbs because volatile oils are supposed to be a key content for various pharmacological effects. The percent essential oil of Elettaria cardamom, Cinnamomum zeylinicum, Carum carvi, Origanum vulgare, and Syzigium aromaticum ranges from 10.0-14.5, 4.0-6.2, 4.0-5.6,
3.0-4.6 and 1.5-3.0 (Table 4) which is according to BP [17] limit. Thus the samples contain sufficient amount of essential oil for medicinal use [23]. 
Phytopharmacognostic Evaluation and Fourier Transform Infrared Fingerprint in the Quality Control of Various Culinary Herbs: An Ultimate Remedy in Asia

Table 4. Assay of \% Essential Oil in Elettaria cardamom, Cinnamomum zeylinicum, Carum carvi, Origanum vulgare, and Syzigium aromaticum.

\begin{tabular}{|c|c|c|}
\hline Test Sample & Essential oil (ml) & $\%$ content Essential oil \\
\hline \multicolumn{3}{|c|}{ Elettaria cardamom } \\
\hline $\mathrm{Cd}-1$ & 2.0 & 10.0 \\
\hline Cd-2 & 2.9 & 14.5 \\
\hline Cd-3 & 2.8 & 14.0 \\
\hline Cd-4 & 2.3 & 11.5 \\
\hline Cd-5 & 2.2 & 11.0 \\
\hline \multicolumn{3}{|c|}{ Cinnamomum zeylinicum } \\
\hline $\mathrm{Ci}-1$ & 2.0 & 4.0 \\
\hline $\mathrm{Ci}-2$ & 2.9 & 5.8 \\
\hline Ci-3 & 2.9 & 5.8 \\
\hline $\mathrm{Ci}-4$ & 2.5 & 5.0 \\
\hline Ci-5 & 3.1 & 6.2 \\
\hline \multicolumn{3}{|l|}{ Carum carvi } \\
\hline $\mathrm{Ca}-1$ & 2.0 & 4.0 \\
\hline Ca-2 & 2.5 & 5.0 \\
\hline $\mathrm{Ca}-3$ & 2.8 & 5.6 \\
\hline $\mathrm{Ca}-4$ & 2.8 & 5.6 \\
\hline $\mathrm{Ca}-5$ & 2.8 & 5.6 \\
\hline \multicolumn{3}{|c|}{ Origanum vulgare } \\
\hline $0-1$ & 1.8 & 3.6 \\
\hline $0-2$ & 2.3 & 4.6 \\
\hline O-3 & 2.0 & 4.0 \\
\hline $0-4$ & 1.5 & 3.0 \\
\hline $0-5$ & 2.0 & 4.0 \\
\hline \multicolumn{3}{|c|}{ Syzigium aromaticum } \\
\hline $\mathrm{Cl}-1$ & 3.0 & 2.0 \\
\hline $\mathrm{Cl}-2$ & 2.7 & 1.5 \\
\hline $\mathrm{Cl}-3$ & 2.5 & 3.0 \\
\hline $\mathrm{Cl}-4$ & 2.5 & 3.0 \\
\hline $\mathrm{Cl}-5$ & 2.5 & 3.0 \\
\hline
\end{tabular}

\section{Fourier transforms infrared spectroscopy (FTIR)}

The FTIR spectra of all the crude drug samples (Elettaria cardamom, Cinnamomum zeylinicum, Carum Carvi, Origanum vulgare, Syzigium aromaticum) are shown in Figure 6 and the details of the spectral assignments are given in Table $\mathbf{5}$. 
Phytopharmacognostic Evaluation and Fourier Transform Infrared Fingerprint in the Quality Control of Various Culinary Herbs: An Ultimate Remedy in Asia

Table 5. FTIR spectral assignments of Elettaria cardamom, Cinnamomum zeylinicum, Carum Carvi, Origanum vulgare, and Syzigium aromaticum.

\begin{tabular}{|c|c|c|c|}
\hline Name of Plant & $\begin{array}{c}\text { Absorption Frequency } \\
\left(\mathrm{cm}^{-1}\right)\end{array}$ & Types of Absorption & Interference \\
\hline \multirow{3}{*}{ Elettaria cardamom } & $3550-3200$ & Broad Stretching & $\mathrm{O}-\mathrm{H}$ alcohol \\
\hline & 1690 & Stretching & Alkenes present \\
\hline & 1000 & Mid, sharp, Stretching & C-O carbonyl present \\
\hline \multirow{3}{*}{ Cinnamomum zeylinicum } & $3000-3100$ & Stretching & $\mathrm{CH}$ bonds \\
\hline & $1640-1680$ & Mid, sharp & $\mathrm{C}=\mathrm{C}$ \\
\hline & $1690-1760$ & Stretching & $\mathrm{C}=\mathrm{O}$ present \\
\hline \multirow{3}{*}{ Carum Carvi } & 1750 & Stretching & $\mathrm{C}=\mathrm{O}$ Carboxylic acid \\
\hline & 1010 & Stretch & C-O carbonyl group \\
\hline & $2800-3000$ & Medium stretch & C-H stretch (alkanes) \\
\hline \multirow[t]{5}{*}{ Origanum vulgare } & $3200-3300$ & Stretching & $\begin{array}{l}\text { Amine }(\mathrm{N}-\mathrm{H}) \text { group present } \\
\text { (characteristic of amino acid) }\end{array}$ \\
\hline & $3000-2900$ & Medium stretch & C-H stretch (alkanes) \\
\hline & 1750 & Stretching & Esters (lactone) \\
\hline & 1610 & Stretching & $C=C \alpha, \beta$-unsaturated ketone \\
\hline & 1020 & Stretch & C-O carbonyl group \\
\hline \multirow[t]{4}{*}{ Syzigium aromaticum } & $3000-2900$ & Weak Stretching & $\mathrm{O}-\mathrm{H}$ alcohol \\
\hline & 1510 & Sharp stretching & Aromatic ring may be present \\
\hline & 1020 & Sharp stretching & C-O carbonyl may be present \\
\hline & 1290 & Stretching & C-N aromatic amine \\
\hline
\end{tabular}

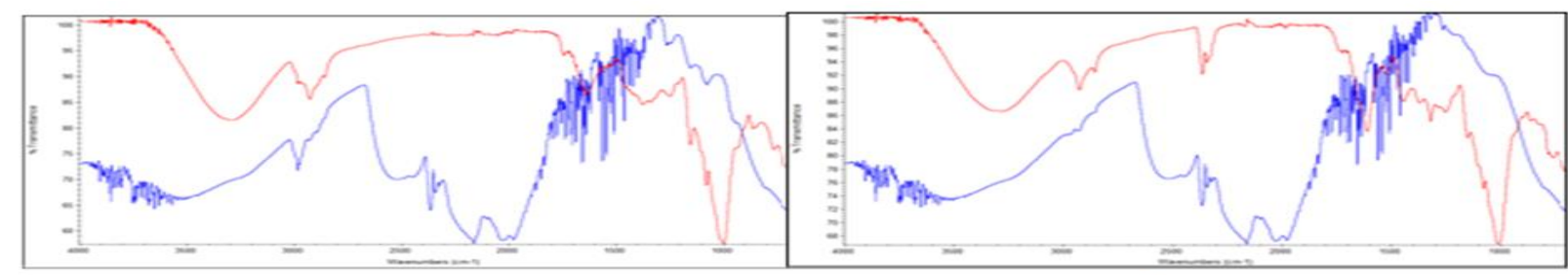

(a)

(b)

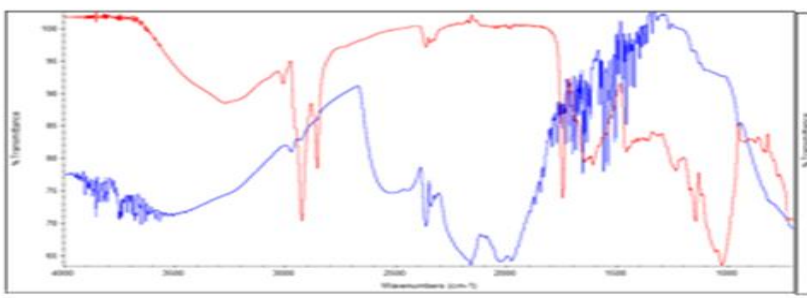

(c)

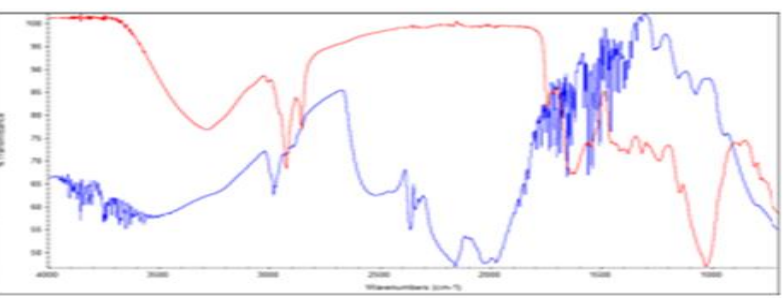

(d)

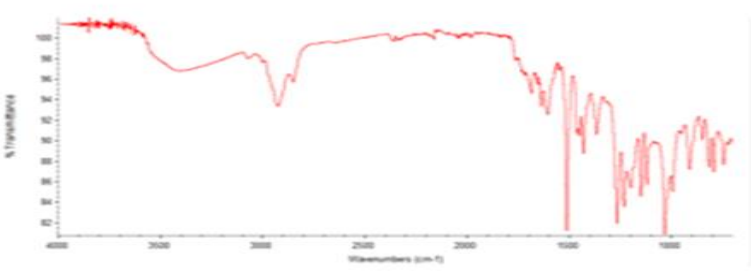

(e)

Figure 6. FTIR spectra of herbal material: (a) Elettaria cardamom (b) Cinnamomum zeylinicum (c) Carum Carvi (d) Origanum vulgare (e) Syzigium aromaticum. 


\section{DISCUSSION}

Quality of standard herbal products is a burning issue in Pakistan and now it is the time to play a role in maintaining the quality of raw material used in the formulation of commercial products. Regrettably, there is no perception in herbal drug producer to ensure and certify the quality of their products or the raw material used in the formulation. Therefore, the study was subject to different methods and protocols for evaluation of raw herbs.

Powdered microscopy is a technique fruitful for evaluation and identification of quality herbal products. The test drugs were evaluated under microscope to confirm the major diagnostic elements and it was found that the sample of Elettaria cardamom contains testa made up of outer epidermis and parenchyma cells, thick-walled sclerenchymatous cells, a layer rectangular cells enclosed with volatile oil and sheet of cells which are thin-walled and flattened (Table 1; Figure 1). The sclereid cells of Cinnamomum zeylinicum are thickened wall, channelled and pitted with cork fragments. There can be seen certain parenchymatous cells enclosed with calcium oxalate crystals (Table 1; Figure 2). Powdered microscopy of Carum carvi reveals spiral vessels accompanied by sclerenchymatous fibres, trichomes, anomocytic stomata and fragments of the secretory cells composed of yellowish-brown or brown, thin-walled, polygonal secretory cells(Table 1; Figure 3). Origanum vulgare shows covering trichomes and glandular trichomes, fine needles of calcium oxalate and cells with finely and irregularly thickened walls, diacytic stomata(Table 1; Figure 4). Lastly the characterstics feature of the powder microscopy of Syzigium aromaticume xhibited hypanthium containing large oil glands, tiny fibres, parenchyma cells enclosed calcium oxalate crystals and multiple pollen grains triangular in shape (Table 1; Figure 5).

The enumerated quality control test given in BP [17] were executed with the aim of checking the identity and purity [24, 25]. Primarily, the physicochemical stability of culinary herbs were analyzed by various physicochemical test such as,foreign matter, moisture content, ash content, mentioned in the monograph. Subsequently several analytical methods have been applied likewise TLC, Assay and FTIR to identify and determine the percent volatile content and functional group present in selected samples [26].

The test samples were found to be of pharmacopoeial standard as they qualified test for foreign matter (Table 2). None of the sample exceeded $6 \%$ limit as mentioned in BP [17]. The increased moisture in herbal raw material may accelerate microbial growth, and subsequently to putrefaction and decay of the drug [27]. Consequently, decreased moisture is virtuous for upholding the quality [28, 29]. The low content of moisture is good for the quality of material. All the samples indicated reduced moisture content as mentioned in Table 2 which reinforces a good quality material [17]

The Ash content is one of the important physicochemical parameter to check the quality of drugs such as cinnamon. All the samples comply with the BP limit of $6 \%$. Ash content is a key parameter to detect the presence of inorganic matter or the amount of minerals such as as $\mathrm{Na}^{+}$(Sodium), $\mathrm{K}^{+}$(Potassium), and $\mathrm{Ca}^{2+}$ (Calcium) in herbs. Inorganic matters are responsible for catalyzing degradation reactions. The ash values of all five test samples are within a range of maximum ash value specified in BP [17] i.e. $6 \%$ percent as presented in Table 2. It indicates that all the samples comply with the BP standard and have ash values within the specified limit of inorganic matter. The increased limits of minerals can significantly potentiate various clinical conditions such as arrhythmia, hyperlipidemia, hypercalcemia etc.

TLC identifies and determines the purity of sample by corresponding with standard spot under specified solvent system. The slight deviation in $\mathrm{R}_{\mathrm{f}}$ value may be due to high water content and any variation in the solvent system. All the spots of selected samples of herbs (Elettaria cardamom,cinnamomum zeylinicum,Carum carvi, Origanum vulgare and Syzigium aromaticum) are corresponded to the standard spot. Thus, all the $R_{f}$ values shown in Table 3 are corresponding each other.

All the selected culinary herbs (Elettaria cardamom, Cinnamomum zeylinicum, Carum carvi, Origanum vulgare, and Syzigium aromaticum) were determined for percent volatile oil content. Since, It is now been very common with herbs which are priory being subjected to exhaustion of volatile oil. Thus, this assay is considered to be the pillar for assessing locally available herbs which should not be exhausted because the volatile content is responsible for various 
therapeutic outcomes [30]. The \% volatile oil is also according to the BP limits as mentioned in Table 4. The FTIR assignments of all the selected samples of culinary herbs (Elettaria cardamom, cinnamomum zeylinicum, Carum carvi, Origanum vulgare and Syzigium aromaticum) are represented in Table $\mathbf{5}$ which shows the presence of various functional group which would be helpful in determination and structure elucidation of various constituent in selected samples using Mass spectrometry and NMR technique. Even then, appropriate utilization of traditional medicines in the health care system exclusively in the era of biological threats like COVID 19 which globally change focus on stenghtening immune system to fight with modern diseases [31-34]. The Ministry of Health Pakistan along with National Council of Tibb (NCT), a regulatory authority for traditional and herbal system of medicine is determined to take measurements for quality assurance of herbs and herbal medicines. Though there are various measures have been taken to establish quality assured methodologies for herbal standardization in latest studies $[35,36]$.

\section{CONCLUSION}

The study subjected to different methods and protocols for evaluation of raw herbs. Culinary herbs which are commonly used as raw materialsin various formulations to treat variety of diseases have been selected i.e. Elettaria cardamomum (cardamom), Cinnamomum zeylanicum (cinnamon), Carum carvi (caraway), Oreganum vulgare (oregano) and Syzigium aromaticum (clove). The study showed that the raw material collected was of good quality and establishing proper quality control methods will be beneficial for herbal and cosmeceutical industries. By applying these methods they can proceed to export and capture international market.

\section{Declaration of interest}

The authors declare that there is no conflict of interest regarding the publication of this paper.

\section{REFERENCES}

1. Kamboj A. Analytical evaluation of herbal drugs. INTECH Open Access Publisher. 2012: 23-60.

2. Patil PS, Shettigar R. An advancement of analytical techniques in herbal research. J Adv Sci Res. 2010; 1(1):8-14.
3. Baquar SR. The scope of herbal medicine in Pakistan. J. Baqai Med. Univ. 1998; 1:7-31.

4. Bhutani KK. Herbal medicines an enigma and challenge to science and directions for new initiatives. Indian J Nat Prod. 2003; 19(1):3-8.

5. Mukherjee PK. Quality control of herbal drugs: an approach to evaluation of botanicals. Business Horizons; 2002.

6. Gruenwald J. The global herbs \& botanicals market. Nutraceuticals World. 2008.

7. Gupta AK. Quality standards of Indian medicinal plants, Vol. 1, Indian Council of Medical Research, New Delhi, India. 2003: 262.

8. Chauhan VS. Standardizing herbs and intermediates-newer approaches. The Pharma Review. 2006; 2:37-44.

9. Verma S, Singh SP. Current and future status of herbal medicines. Veterinary world. 2008; 1(11):347.

10. World Health Organization. Quality control methods for medicinal plant materials. World Health Organization; 1998.

11. WHO. WHO Monographs on Selected Medicinal Plants. World Health Organization, Geneva. 2002.

12. WHO. WHO Monographs on Selected Medicinal Plants. World Health Organization, Geneva. 2015.

13. Rasheed NM, Gupta VC. Standardization of a compound Unani herbal formulation "Qurs-e-Luk" with modern techniques. Pharmacognosy research. 2010; 2(4):237.

14. Mabberley DJ. Mabberley's Plant-book: A Portable Dictionary of Plants, their Classifications and Uses. Cambridge University Press, Elsevier. 2008.

15. Mills S, Bone K. Principles and practice of phytotherapy. Modern herbal medicine. Churchill Livingstone; 2000.

16. Houghton PJ. Establishing identification criteria for botanicals. Drug Information Journal. 1998; 32(2):461-9.

17. British Pharmacopoeia. Her Majesty's Stationary Office, London, UK. 2016:178-779.

18. Embuscado ME. Spices and herbs: Natural sources of antioxidants-a mini review. Journal of functional foods. 2015; 18:811-9.

19. Khezeli T, Daneshfar A, Sahraei R. A green ultrasonic-assisted liquid-liquid microextraction based on deep eutectic solvent for the HPLC-UV determination of ferulic, caffeic and cinnamic acid from olive, almond, sesame and cinnamon oil. Talanta. 2016; 150:577-85.

20. Ashokkumar R, Ramaswamy M. Phytochemical screening by FTIR spectroscopic analysis of leaf extracts of selected Indian medicinal plants. International journal of Current Microbiology and applied Sciences. 2014; 3(1):395-406. 
21. Calixto JB. Efficacy, safety, quality control, marketing and regulatory guidelines for herbal medicines (phytotherapeutic agents). Brazilian Journal of medical and Biological research. 2000; 33(2):179-89.

22. Grzeszczuk M, Jadczak D. The estimation of biological value of some species of spice herbs. InIV Balkan Symposium on Vegetables and Potatoes 830 2008; (pp. 681-686).

23. Gupta C, Garg AP, Uniyal RC, Kumari A. Comparative analysis of the antimicrobial activity of cinnamon oil and cinnamon extract on some food-borne microbes. African Journal of Microbiology Research. 2008 Sep; 2(9):247-51.

24. Hasan SZ, Misra V, Singh S, Arora G, Sharma S, Sharma S. Current status of herbal drugs and their future perspectives. InBiol Forum Int J 2009; $1(1): 12-17$.

25. Rajani M, Kanaki NS. Phytochemical standardization of herbal drugs and polyherbal formulations. In: Bioactive Molecules and Medicinal Plants. Springer. 2008; 349-369.

26. Sahil K, Sudeep B, Akanksha M. Standardization of medicinal plant materials. International Journal of Research in Ayurveda \& Pharmacy. 2011; 2(4):1100-9.

27. Shrikumar S, Maheshwari U, Sughanti A, Ravi TK. WHO guidelines for herbal drug standardization. World Health Organization, Geneva. 2006.

28. Anubhuti P, Rahul S, Kant KC. Standardization of fennel (Foeniculum vulgare), its oleoresin and marketed ayurvedic dosage forms. International Journal of Pharm Sci and Drug Res. 2011; $3(3): 265-9$.

29. Sopan BP, Atmaram DT, Raghunath PV and Radhesham KK. Review on standardization parameter of churn. World J. Pharm. Pharm. Sci. 2012; 1:1260-1274.

30. Ozel MZ, Goguş F, LewisAC. Comparison of direct thermal desorption with water distillation and superheated water extraction for the analysis of volatile components of Rosa damascene Mill. using GCxGC-TOF/MS. Analytica Chimica Acta. 2006; 566: 172-177.

31. Sharma R, Kumari N, Ashawat MS, Verma CP. Standardization and phytochemical screening analysis for herbal extracts: Zingiber officinalis, Rosc., Curcuma longa Linn., Cinnamonum zeylanicum Nees., Piper longum, Linn., Boerhaavia diffussa Linn. Asian Journal of Pharmacy and Technology. 2020;10(3):127-33.

32. Venkateswarlu G, Ganapaty S, Sudhakar AM. Preparation of Triphala Churna using the Ingredients Obtained from Local Market and Comparative Standardization. Pharmacognosy Journal. 2019; 11(1).

33. Gaonkar VP, Hullatti K, Mannur V. Standardization of Trigonella foenum-graecum L. Seeds: A Quality by Design Approach. proteins. 2020; 12:13.

34. Hovijitra RS, Choonharuangdej S, Srithavaj T. Effect of essential oils prepared from Thai culinary herbs on sessile Candida albicans cultures. Journal of oral science. 2016; 58(3):365-71.

35. Ulewicz-Magulska B, Wesolowski M. Total phenolic contents and antioxidant potential of herbs used for medical and culinary purposes. Plant Foods for Human Nutrition. 2019; 74(1):61-7.

36. Rashid S, Zafar M, Ahmad M, Lone FA, Shaheen S, Sultana S, Ashfaq S, Shinwari MI. Microscopic investigations and pharmacognostic techniques used for the standardization of herbal drug Nigella sativa L. Microscopy research and technique. 2018;81(12):1443-50. 